\title{
Front Matter: Volume 11591
}

, "Front Matter: Volume 11591," Proc. SPIE 11591, Sensors and Smart Structures Technologies for Civil, Mechanical, and Aerospace Systems 2021, 1159101 (6 May 2021); doi: 10.1117/12.2597402 


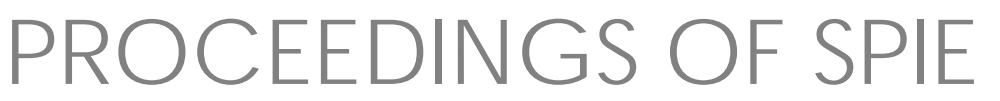

\title{
Sensors and Smart Structures Tec hnologies for Civil, Mechanical, and Aerospace Systems 2021
}

\author{
Haiying Huang \\ Daniele Zonta \\ Zhongqing Su \\ Editors
}

22-26 March 2021

Online Only, United States

Sponsored and Published by

SPIE

Volume 11591 
The papers in this volume were part of the technical conference cited on the cover and title page. Papers were selected and subject to review by the editors and conference program committee. Some conference presentations may not be available for publication. Additional papers and presentation recordings may be a vaila ble online in the SPIE Digital Libra ry at SPIEDigita lLibrary.org.

The papers reflect the work and thoughts of the authors and a re published herein as submitted. The publisher is not responsible for the valid ity of the information or for any outc omes resulting from reliance thereon.

Please use the following format to cite material from these proceedings: Author(s), "Title of Paper," in Sensors and Smart Structures Technologies for Civil, Mechanical, and Aerospace Systems 2021, edited by Haiying Huang, Daniele Zonta, Zhongqing Su, Proc. of SPIE 11591, Seven-digit Article CID Number (DD/MM/YYYY); (DOI URL).

ISSN: 0277-786X

ISSN: 1996-756X (electronic)

ISBN: 9781510640115

ISBN: 9781510640122 (electronic)

Published by

SPIE

P.O. Box 10, Bellingham, Wa shington 98227-0010 USA

Telephone +1 3606763290 (Pacific Time)

SPIE.org

Copyright @ 2021 Society of Photo-Optic al Instrumentation Engineers (SPIE).

Copying of material in this book for intemal or personal use, or for the intemal or personal use of specific clients, beyond the fair use provisions granted by the U.S. Copyright Law is authorized by SPIE subject to payment of fees. To obta in permission to use and share a ricles in this volume, visit Copyright Clearance Center at copyright.com. Other copying for republication, resale, advertising or promotion, or any form of systematic or multiple reproduction of any material in this book is prohibited except with pemission in writing from the publisher.

Printed in the United States of Americ a by Curran Associates, Inc., under license from SPIE.

Publication of record for individual papers is online in the SPIE Digital Library.

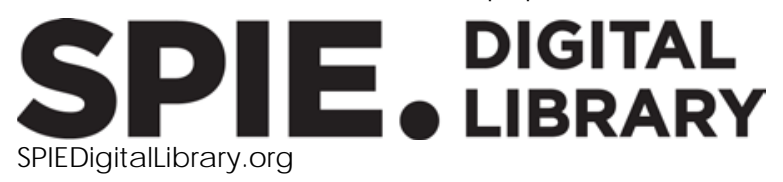

\footnotetext{
Paper Numbering: A unique c itation identifier (CID) number is a ssigned to each artic le in the Proceedings of SPIE at the time of public ation. Utilization of CIDs a llows a rtic les to be fully citable as soon as they are published online, and connects the same identifier to all online and print versions of the public ation. SPIE uses a seven-digit CID article numbering system structured as follows: - The first five digits correspond to the SPIE volume number.

- The last two digits indic ate public ation order within the volume using a Base 36 numbering system employing both numerals and letters. These two-number sets start with $00,01,02,03,04$, $05,06,07,08,09,0 A$, OB ... 0Z, followed by 10-1Z, 20-2Z, etc. The CID Number appears on each page of the manuscript.
} 


\section{Contents}

KEYNOTE SESSION

1159105 Strategies forthe design and operation of resilient extratemestrial habitats (Keynote Paper) [11591-2]

\section{SHM FOR CIVIL INRASTRUCTURE}

$1159106 \quad$ Evaluating the impact of road quality in driving behavior of autonomous vehicles [11591-3]

1159107 Use of transient pressure data in a drinking water transmission system to assess pipe reliability [11591-4]

1159109 Bridge damage identification through frequency changes [11591-6]

\section{ADDIIVE MANUFACTURING OF SENSORS}

11591 OB On the performance of additively manufactured CNF/ PLA piezoresistive strain sensors [11591-8]

$115910 \mathrm{E}$ Effect of phase fluctuation at high speed of smart gear on retum loss of rec eiver antenna [11591-11]

11591 OF Additive manufacturing of flexible nanocomposite SAW sensor for strain detection [11591-12]

\section{MACHINE LEARNING FOR STRUCTURAL HEALTH MONITORING}

$115910 \mathrm{OH}$ Long short-tem memory networks with attention leaming for high-rate structural health monitoring [11591-14]

11591 ol Investigation of monitoring methods for ultrasonic metal welding [11591-15]

11591 OK Fatigue damage prognosis of adhesively bonded joints via a sumogate model [11591-17]

$115910 \mathrm{~L}$ Recursive hybrid GA and moving window hybrid GA to parameter identification of structural systems with passive control devices [11591-18] 
11591 ON An acoustic sensor network for planetary exploration [11591-20]

11591 0Q An in-situ real-time hidden damage inspection on C-17 Globemaster III composite aileron using LSP tec hnique under themal excitation [11591-23]

11591 OR Comparison of image comelation algonithms for hidden damage laser speckle photometry [11591-24]

11591 OS Probabilistic fatigue life prediction foradhesively bonded joints via sumogate model [11591-25]

$115910 T$ Sample retum containerization and planetary protection using brazing for breaking the chain of contact to Mars [11591-26]

11591 OU Multipoint temperature monitoring based on a regenerated fiber Bragg grating temperature sensor anay in copper casting [11591-27]

\section{ACOUSTIC BMISSION-BASED MONITORING}

$115910 \mathrm{~V}$ Effectiveness of acoustic emission monitoring for in-senice prestressed concrete bridges [11591-28]

11591 OW Simultaneous amplification of guided wave modes in polymer pipes via a structurally embedded gradient index lens [11591-29]

$115910 \mathrm{X}$ Comosion monitoring and mitigation in conc rete structures using a 3D printing and Intemet of Things approach [11591-30]

\section{EEC TRICALIMPEANCE TOMOGRAPHY}

1159110 Inverse detemination of delamination shape and size in self-sensing composites using electrical impedance tomography and genetic algonithms [11591-33]

1159112 Deep leaming scheme PSPNet for electrical impedance tomography [11591-35]

\section{MACHINE LEARNING FOR CIVILAPPUCATIONS}

1159113 Active scour monitoring using ultrasonic time-domain reflectometry to detecta soil interface [11591-36]

1159114 Determination of critical contourarea in SAR images of conc rete for subsurface moisture sensing [11591-37] 
11591 1B Missing area detection and damage mapping method based on field-of-view estimation in UAV-based bridge inspection [11591-44]

11591 1C Vibration-based damage imaging via high-speed cameras with 3D digital image comelation using wavelet transform [11591-45]

\section{ENERGY HARVESTING AND ACTUATORS}

11591 1D Bio-inspired metasurface skin to enhance the performance of blue energy harvesting [11591-46]

11591 1E A knee energy harvester with variable transmission ratio [11591-47]

11591 1G Feasibility of using a high-power electromagnetic energy havester to powerstructural health monitoring sensors and systems in transportation infrastructures [11591-49]

11591 1H Expenimental study on dynamic load line for magnetostric tive actuator [11591-50]

\section{CIVILSHM}

11591 1] MAP-based model updating of building structures under earthquakes using limited acceleration measurements [11591-52]

11591 1K Optimal stochastic data collection and transmission policy for self-sustaining structural health monitoring sensing architectures [11591-53]

11591 1M On the development of an improved magnetic-based comosion sensor [11591-55]

\section{REXIBIE SENSORS}

11591 1Q Monitoring impact damage in composites with large area sensing skins [11591-59]

11591 1R Expenimental validation of textured sensing skin for fatigue crack monitoring [11591-60]

11591 is Modular \#G based technical textile for temperature and stain monitoring [11591-61]

$115911 T \quad$ Effect on plasma treatment on adhesive bonding strength [11591-62] 
$115911 \mathrm{U}$ Surface displacement field by pulsed laser inadiation on metallic surfaces [11591-63]

11591 IV Investigation on acoustic wave transfer variation between fibers of different diameters and types using acoustic coupler [11591-64]

11591 IW F Fiber Bragg grating sensor response to ultrasonic Lamb waves with varying frequency [11591-65]

11591 1X The contactless/ contact type detection technologies of chemical warfare agents [11591-66]

11591 1Y An analytical investigation on the resonances of surface bonded piezoelectric wafer active transducers (PWaTs) [11591-67]

$115911 Z$ Sensitization detection of aluminum alloy based on the resonant parameters of surface bonded piezoelectric wafer active sensor (PWAS) [11591-68]

\section{POSTER SESSION}

1159121 Optimization of the active controlled mic rofluidic valve with annular boundary [11591-70]

1159124 Expenimental study on a novel comosion sensor for steel strand using \#G [11591-73]

$1159125 \quad$ Image-based transmission tower component identification for operation maintenance using deep leaming [11591-74]

1159126 Mechanical, acoustic and electrical properties of graphene-enhanced mortars [11591-75]

1159127 Monitoring the nonlinear parameters of nano-enhanced cement based structures during their curing process [11591-76]

1159128 AE monitoring of the fracture behavior of mortar specimens modified with waterproofing adhesives [11591-77]

1159129 Monitoring the fracture behavior of epoxy resin repaired fiber reinforced concrete specimens by acoustic emission [11591-78]

$115912 \mathrm{~B}$ Meteorological data prediction for senvice environments of bridge using spatial interpolation method [11591-80]

11591 2D Decoupled temperature and strain measurement with regenerated fiber Bragg gratings during an aluminum casting process [11591-82] 